\title{
OPTIMIZATION OF PROCESSED FISHERY PRODUCTS ON TELUK SANTONG VILLAGE USING LINEAR PROGRAMMING METHOD
}

\author{
Zulkieflimansyah $^{1}$, Muhammad Nurjihadi ${ }^{2}$, Rudi Masniadi ${ }^{3}$, \\ Fitriah Permata $\mathrm{Cita}^{4}$, Diah Anggeraini Hasri ${ }^{5}$ \\ ${ }^{1}$ Senior Lecturer, Master Management of Innovation, Sumbawa University of Technology \\ 2,3,4,5 Lecturer, Faculty of Economics and Business, Sumbawa University of Technology
}

Article DOI: https://doi.org/10.36713/epra9081 DOI No: 10.36713/epra9081

\begin{abstract}
This study aims to optimize processed fishery products in Teluk Santoni Village with a constraint factor: Fish Resources (SDI) availability. The analytical tool used in this research is linear programming, maximizing the profit of processed fishery products with limitations on the availability of human resources, production capacity, and total production costs. Based on the results of data analysis with the help of the Linear Program Solver (LiPS) software, it was found that to obtain maximum profit, the strategy that needs to be done is to produce crabs 10/3 times the average amount, 2.5 times salty, empek-empek and shrimp paste, produced two times the usual production amount and did not produce shredded fish and fish crackers. The total profit obtained from the optimization is Rp. 18.85 million per month.
\end{abstract}

KEYWORDS: optimization, processed fishery products, linear programming

\section{INTRODUCTION}

Management of Coastal Areas and Small Islands (WP3K) is a mandate in Law no. 27 of 2007(Directorate-General for Strengthening the Competitiveness of Marine and Fishery Products, 2018). This policy requires the government to be able to prepare planning documents very carefully to improve the welfare of coastal communities. One of the efforts to strengthen interest in coastal areas is utilizing fishery products. West Nusa Tenggara (NTB) is one of the provinces with a sea area of 29,159.04 km2 (59.13\%) of the total area. In addition, NTB Province has a relatively complete aquatic ecosystem such as pelagic seas, demersal seas, coastal ecosystems, and small islands rich in coral reefs, seagrass beds, mangroves, to public waters such as reservoirs, lakes, rivers, and reservoirs that are abundant in resources. Fisheries and marine(Directorate-General for Strengthening the Competitiveness of Marine and Fishery Products, 2018). The fishery production in NTB in 2020 is presented in Table 1.

Table 1. NTB Fisheries in 2020

\begin{tabular}{|l|l|l|l|l|}
\hline \multicolumn{1}{|c}{ Country/City } & \multicolumn{4}{c|}{ Aquaculture Production Value } \\
\cline { 2 - 5 } & Marine KJA & Other Sea & Seaweed & \multicolumn{1}{c|}{ Amount } \\
\hline West Lombok & 258,145 & - & $110,967,760$ & $111,225,905$ \\
\hline central Lombok & $2,248,125$ & - & $80,407,931$ & $82,656,056$ \\
\hline East Lombok & $27,698,390$ & - & $15,136,643$ & $42,835,033$ \\
\hline West Sumbawa & - & - & $25,234,449$ & $25,234,449$ \\
\hline Sumbawa & $30,542,700$ & 976,800 & $1,627,671,654$ & $1,659,191,154$ \\
\hline Dompu & - & - & $9,151,300$ & $9,151,300$ \\
\hline Bima & $10,062,600$ & - & $125,363,775$ & $135,426,375$ \\
\hline
\end{tabular}




\begin{tabular}{|l|l|l|l|l|}
\hline Bima City & $1,254,850$ & - & - & $1,254,850$ \\
\hline Amount & $72,064,810$ & 976,800 & $1,993,933,511$ & $2,066,975,121$ \\
\hline
\end{tabular}

Source: Department of Marine Affairs and Fisheries NTB

Fish is one of the marine products with a perishable nature (Alam et al., 2021). This characteristic results in fish being unable to be consumed from a location far from the place of production. To prevent this, preventive measures such as preservation and processing are needed. (Widyaningsih \& Martini, 2006). The fish processing process aims to stop and inhibit the cause of the decline in fish quality so that it remains in good condition until it is accepted by consumers(Andarwulan et al., 2011).

The fish processing industry has an essential role in achieving the United Nations (UN) Sustainable Development Goals (SDGs) (Riniwati, 2020). The fish processing industry has contributed to improving the economic welfare of coastal communities and fisheries (SDGs 14), which in turn has the potential to eradicate poverty (SDGs 1), achieve food security and improve nutrition (SDGs 2), promote sustainable, inclusive, and sustainable economic growth ( SDGs 8), and reducing inequality (SDGs 10)(Diedrich et al., 2019).

Fish that has been processed will have a higher added value and be able to get more profits when compared to fish that have not been processed (Mahardana et al., 2015). Of course, fishery processing that is not adequately managed in terms of distribution networks will have a negative effect on the sector, of course (Karo, 2016). Thus, in order to improve the management of fishery products using linear programming, this research was carried out. Fishery product processors do this to increase their profits and make their operations more costand fish-efficient.

\section{Literature Review}

The optimization of processed products can be done in two ways: maximizing profits and minimizing product distribution(Riniwati, 2020). One of the methods commonly used in optimization is Linear Programming (LP). This method is used for planning that is analytical by using a mathematical model. This method aims to formulate a strategy regarding the allocation of limited resources and funds to achieve the desired goals or objectives optimally.

Linear Programming (LP) is a mathematical programming in which there is an objective function in the form of an unknown linear and constraint functions in the form of linear equations or linear inequalities. (Kakay \& J, 2008).In general, the form of LP is(Ziegel \& Winston, 1988):

Maximize or minimize the objective function

$$
Z=C_{1} X_{1}+C_{2} X_{2}+\cdots+C_{n} X_{n}
$$

with limitations

$$
\begin{gathered}
a_{11} X_{1}+a_{12} X_{2}+\cdots+a_{1 n} X_{n}=/ \leq / \geq b_{1} \\
a_{21} X_{1}+a_{22} X_{2}+\cdots+a_{2 n} X_{n}=/ \leq / \geq b_{2} \\
\cdots \\
a_{m 1} X_{1}+a_{m 2} X_{2}+\cdots+a_{m n} X_{n}=/ \leq / \geq b_{m} \\
X_{1}, X_{2}, \cdots, X_{n} \geq 0 .
\end{gathered}
$$

Variable $X_{1}, X_{2}, \ldots, X_{n}$ is a decision variable or a problem variable. is the contribution of each problem variable to the goal to be optimized. The symbol is the use per unit of the problem variable against resource limitations, while is the amount of each resource availability. $C_{1}, C_{2}, \ldots, C_{n} a_{11}, a_{12}, \ldots, a_{m n} b_{1}, b_{2}, \ldots, b_{m}$

\section{METHODOLOGY}

This study aims to optimize processed fishery products in Teluk Santong Village based on the availability of Fish Resources (SDI). Optimization is carried out on processed fishery products based on the product's ability to generate large profits with a limit on the number of SDI. The optimization model used is Linear Programming (LP). This linear programming will then be completed with the help of the Linear Program Solver (LiPS) software. The objects used in this study are all processed fishery products in Teluk Santong Village, namely crab products, salty, shrimp paste, fish crackers, empek-empek and shredded fish. The stages in this research are:

1. Data collection

2. Determination of variables Problems that cause maximum or minimal optimization goals

3. Model formulation is to determine the objective function and constraint function 
4. Input linear equations into the Linear Program Solver (LiPS) software

5. Running software

The variables used in the formulation of the LP model for processed fishery products are assumed to be deterministic and constant. The variables are:

1. Profit

2. SDI Needs

3. Production Quantity

4. Production cost

The data collection process was carried out through interviews and observations to businesses that were engaged in the processing of fishery products in Teluk Santong Village. Suppose Xi is the number of products produced, with $\mathrm{i}=1,2,3,4,5,6$. Then suppose $\mathrm{X} 1$ is the number of crab products, $\mathrm{X} 2$ is salty, $\mathrm{X} 3$ is shrimp paste, $\mathrm{X} 4$ is shredded fish, X5 is empek-empek and X6 is fish cracker. In this study, the form of LP that will be completed is Maximizing $\mathrm{Z}$ value

$Z=C_{1} X_{1}+C_{2} X_{2}+C_{3} X_{3}+C_{4} X_{4}+C_{5} X_{5}+C_{6} X_{6}$

Constraint function as follows:

1. Availability of Fish Resources (SDI)

$a_{11} X_{1}+a_{12} X_{2}+a_{13} X_{3}+a_{14} X_{4}+a_{15} X_{5}+a_{16} X_{6} \leq b_{1 i}$

2. Production Limitations

$a_{21} X_{1}+a_{22} X_{2}+a_{23} X_{3}+a_{24} X_{4}+a_{25} X_{5}+a_{26} X_{6} \leq b_{2}$

3. Availability of funds

$a_{31} X_{1}+a_{32} X_{2}+a_{33} X_{3}+a_{34} X_{4}+a_{35} X_{5}+a_{36} X_{6} \leq b_{3}$.

\section{Description:}

C1 : Profit from crab production $(\mathrm{Rp} / \mathrm{month})$

$\mathrm{C} 2$ : Profit from salt production ( $\mathrm{Rp} / \mathrm{month})$

C3 : Profit of shrimp paste production ( $\mathrm{Rp} / \mathrm{month})$

C4 : Profit from the production of shredded fish (Rp/ month)

C5 : The profit of empek-empek production ( $\mathrm{Rp} / \mathrm{month})$

C6 : Profit of fish cracker production ( $\mathrm{Rp} / \mathrm{month})$

$a_{11} \quad$ : Amount crab needs in processed crab products $(\mathrm{kg} / \mathrm{month})$

$a_{12}:$ Number of ebi needs in salted production $(\mathrm{kg} / \mathrm{month})$

$a_{13} \quad$ : Number of ebi needs in shrimp paste production $(\mathrm{kg} / \mathrm{month})$

$a_{14}:$ Total demand for mackerel in the production of shredded fish (kg/month)

$a_{15} \quad$ : Total demand for mackerel in production Empek-empek (kg/month)

$a_{16}:$ Total demand for mackerel in production fish crackers $(\mathrm{kg} / \mathrm{month})$

$a_{21}:$ Number of processed crab products that can be produced ( $\left.\mathrm{kg} / \mathrm{month}\right)$

$a_{22} \quad$ : Number of salty products produced ( $\left.\mathrm{kg} / \mathrm{month}\right)$

$a_{23} \quad$ : Number of shrimp paste products produced (kg/month)

$a_{24} \quad$ : Number of shredded fish products produced $\mathrm{kg} / \mathrm{month}$ )

$a_{25} \quad$ : Number of empek-empek products produced ( $\left.\mathrm{kg} / \mathrm{month}\right)$

$a_{26}:$ Number of fish cracker products produced (kg/month)

$a_{31} \quad$ : Total costs incurred to produce processed crabs ( $\mathrm{Rp} /$ month)

$a_{32} \quad$ : Total cost incurred to produce machine ( $\left.\mathrm{Rp} / \mathrm{month}\right)$

$a_{33} \quad:$ Total costs incurred to produce shrimp paste ( $\mathrm{Rp} /$ month)

$a_{34} \quad$ : Total costs incurred to produce shredded fish ( $\mathrm{Rp} /$ month)

$a_{35} \quad:$ Total costs incurred to produce empek-empek ( $\mathrm{Rp} /$ month)

$a_{36} \quad$ : Total costs incurred to produce fish crackers ( $\mathrm{Rp} /$ month)

$b_{11} \quad$ : Number of available crabs $(\mathrm{kg})$

$b_{12} \quad$ : Amount of available ebi $(\mathrm{kg})$

$b_{13} \quad$ : Number of available mackerel $(\mathrm{kg})$

$b_{21} \quad$ : Crab production capacity $(\mathrm{kg})$

$b_{22} \quad$ : Production capacity salty $(\mathrm{kg})$

$b_{23} \quad$ : Production capacity shrimp paste $(\mathrm{kg})$

$b_{24} \quad$ : Production capacity shredded $(\mathrm{kg})$ 
$b_{25} \quad$ : Production capacity sweets $(\mathrm{kg})$

$b_{26} \quad$ : Production capacity fish crackers $(\mathrm{kg})$

$b_{3} \quad$ : Assumed total availability funds for production capital (Rp)

\section{RESULTS}

\section{Linear Programming Formulation}

\section{Crab Products}

Crab products are the result of processing fishery products that come from crabs after passing through the boiling stage. Crab processing is located in several areas in NTB, one of which is in Teluk Santong Village. Based on data from the Department of Maritime Affairs and Fisheries of NTB in 2017, the boiled crab business is located in Dompu Regency in UD. Mbawi Indah, UD. 76 and Bintang Santong, Sumbawa Regency and UD. East Lombok Blue Sea. Crab production since 2014-2017 has decreased by around 49\%. The variable costs per month for the crab processing industry in Teluk Santong Village are as follows.

Table 2. Cost Components of Processed Crayfish in Teluk Santong Village

\begin{tabular}{lr}
\multicolumn{1}{c}{ Component } & \multicolumn{1}{c}{ Total } \\
Total Receipt & $9,250,000$ \\
\hline Total cost of main raw materials & $5,500,000$ \\
\hline Miscellaneous expense & 75,000 \\
\hline Total cost & $5,575,000$ \\
\hline Profit & $3,675,000$ \\
\hline Production Quantity & $150 \mathrm{~kg}$ \\
\hline SDI Needs (Rajungan) & $150 \mathrm{~kg} / \mathrm{month}$ \\
\hline
\end{tabular}

Source: Primary data processed

2. Salty Products

Masin is a local product of Teluk Santong Village that uses ebi (ebi) as the basic ingredients.Thenus orientalis). Ebi is then fermented together with cayenne pepper. The variable costs for this product are as follows.

Table 3. Cost Components of Salted Products in Teluk Santong Village

\begin{tabular}{|l|r|}
\hline \multicolumn{1}{|c|}{ Component } & \multicolumn{1}{c|}{ Total } \\
\hline Total Receipt & $2,800,000$ \\
\hline Total cost of main raw materials & $1,000,000$ \\
\hline Miscellaneous expense & 60,000 \\
\hline Total cost & 1.060 .000 \\
\hline Profit & $1,740,000$ \\
\hline Production Quantity & $40 \mathrm{~kg} / \mathrm{month}$ \\
\hline SDI Needs (Ebi) & $40 \mathrm{~kg} / \mathrm{month}$ \\
\hline
\end{tabular}

Source: Primary data processed

\section{Terasi Products}

Terasi is a processed fishery product with the basic ingredients of ebi or rebon or small shrimp with a fermentation and drying process. The components of this business can be seen in the following table.

Table 4. Cost Components of Terasi Products in Teluk Santong Village

\begin{tabular}{|l|r|}
\hline \multicolumn{1}{|c|}{ Component } & \multicolumn{1}{|c|}{ Total } \\
\hline Total Receipt & $1,400,000$ \\
\hline Total cost of main raw materials & 500,000 \\
\hline Miscellaneous expense & 140,000 \\
\hline Total cost & 640,000 \\
\hline Profit & 750,000 \\
\hline Production Quantity & $140 \mathrm{cups} / \mathrm{month}$ or $20 \mathrm{~kg} / \mathrm{month}$ \\
\hline SDI Needs (Ebi) & $20 \mathrm{~kg} / \mathrm{month}$ \\
\hline
\end{tabular}

Source: Primary data processed 


\section{Fish Shredded Products}

Shredded fish is a processed product of fish that is seasoned and processed by boiling and drying/draining oil using a spinner. The fish used in this shredded product is mackerel. Mackerel (Scomberomorus commersoni) is one type of fish that is commonly found in the market and the price is relatively cheap.(Parnanto \& Atmaka, 2010). This fish has the characteristics of white flesh, thick and does not contain many spines. The components of shredded fish production can be seen in the following table.

Table 5. Cost Components of Shredded Fish Products in Teluk Santong Village

\begin{tabular}{|l|r|}
\hline \multicolumn{1}{|c|}{ Component } & Total \\
\hline Total Receipt & 400,000 \\
\hline The total cost of main raw materials & 225,000 \\
\hline Miscellaneous expense & 95,000 \\
\hline Total cost & 320,000 \\
\hline Profit & 80,000 \\
\hline Production Quantity & $2 \mathrm{~kg} / \mathrm{month}$ \\
\hline SDI Needs & $5 \mathrm{~kg}$ fish/month \\
\hline
\end{tabular}

Source: Primary data processed

\section{Empek-Empek Products}

Empek-empek is a processed fish product that comes from fish with a mixture of sago flour, which is processed by boiling and frying. This food comes from Palembang, but has been widely developed in other areas. The product variables are detailed in Table 6.

Table 6. Cost Components of Teluk Santong Village's Empek-Empek Products

\begin{tabular}{|l|r|}
\hline \multicolumn{1}{|c|}{ Component } & \multicolumn{2}{c|}{ Total } \\
\hline Total Receipt & 1.350 .000 \\
\hline The total cost of main raw materials & 750,000 \\
\hline Miscellaneous expense & 225,000 \\
\hline Total cost & 975,000 \\
\hline Profit & 375,000 \\
\hline Production Quantity & 1350 pieces $/$ month or equivalent to $15 \mathrm{~kg} / \mathrm{month}$ \\
\hline SDI Needs & $15 \mathrm{~kg} / \mathrm{month}$ \\
\hline
\end{tabular}

Source: Primary data processed

6. Fish Cracker Products

Fish crackers are one of the fish products with the basic ingredients of fish mixed with sago flour, the processing processes are boiling, drying and frying. The variables contained in this product are described in Table 7.

Table 7. Cost Components of Fish Cracker Products in Teluk Santong Village

\begin{tabular}{|l|r|}
\hline \multicolumn{1}{|c|}{ Component } & \multicolumn{1}{c|}{ Total } \\
\hline Total Receipt & 200,000 \\
\hline Total cost of main raw materials & 90,000 \\
\hline Miscellaneous expense & 40,000 \\
\hline Total cost & 130,000 \\
\hline Profit & 70,000 \\
\hline Production Quantity & $4 \mathrm{~kg} / \mathrm{month}$ \\
\hline SDI Needs & $4 \mathrm{~kg} / \mathrm{month}$ \\
\hline
\end{tabular}

Source: Primary data processed

The number of fish is very volatile and in certain seasons it is sometimes very rare, for that, the availability of the amount of fish resources is used the average value per month. The average availability of crabs is $500 \mathrm{~kg} /$ month, the availability of ebi is $250 \mathrm{~kg} /$ month and the availability of mackerel is $30 \mathrm{~kg} /$ month. Due to limited technology and human resources, abon can only be made up to $10 \mathrm{~kg} / \mathrm{month}$, shrimp paste $40 \mathrm{~kg} / \mathrm{month}$, empek-empek $50 \mathrm{~kg} /$ month, crackers $25 \mathrm{~kg} / \mathrm{month}$, salty $100 \mathrm{~kg} / \mathrm{month}$ and crab $500 \mathrm{~kg} / \mathrm{month}$. 
Due to difficulties in financing and financing, it is assumed that the maximum production cost is Rp. 20,000,000,- per month.

Based on these data, the linear programming problem can be modeled as follows.

Maximize profit

$$
Z=3675000 X_{1}+1740000 X_{2}+750000 X_{3}+80000 X_{4}+375000 X_{5}+70000 X_{6}
$$

With obstacles

Fish Resource Constraints

$$
\begin{gathered}
150 X_{1} \leq 500 \\
40 X_{2}+20 X_{3} \leq 250 \\
5 X_{4}+15 X_{5}+4 X_{6} \leq 30
\end{gathered}
$$

Production Constraint

$$
\begin{gathered}
0 \leq 2 X_{4} \leq 10 \\
0 \leq 20 X_{3} \leq 40 \\
0 \leq 15 X_{5} \leq 50 \\
0 \leq 4 X_{6} \leq 25 \\
0 \leq 40 X_{2} \leq 100 \\
0 \leq 150 X_{1} \leq 500
\end{gathered}
$$

Cost Constraint

$$
5575000 X_{1}+1060000 X_{2}+640000 X_{3}+320000 X_{4}+975000 X_{5}+130000 X_{6} \geq 20000000
$$

\section{Optimization Result Analysis}

The solution to the above model using the LiPS program is as follows.

Figure 1. Solution to the LP Problem in Optimizing Processed Products in Teluk Santong Village

$\Rightarrow$ optimal solution Found
$\Rightarrow$ Maximum $=1.885$ e+007
\begin{tabular}{|r|r|r|r|}
\hline wariab1e & va1ue & obj. cost & Reduced cost \\
\hline$\times 1$ & $10 / 3$ & $3.675 \mathrm{e}+006$ & 0 \\
\hline$\times 2$ & 2.5 & $1.740+006$ & 0 \\
\hline$\times 3$ & 2 & 750000 & 0 \\
\hline$\times 4$ & 0 & 80000 & 45000 \\
\hline$\times 5$ & 2 & 375000 & 30000 \\
\hline$\times 6$ & 0 & 70000 & 0 \\
\hline
\end{tabular}

Source: Data Processed with LiPS program

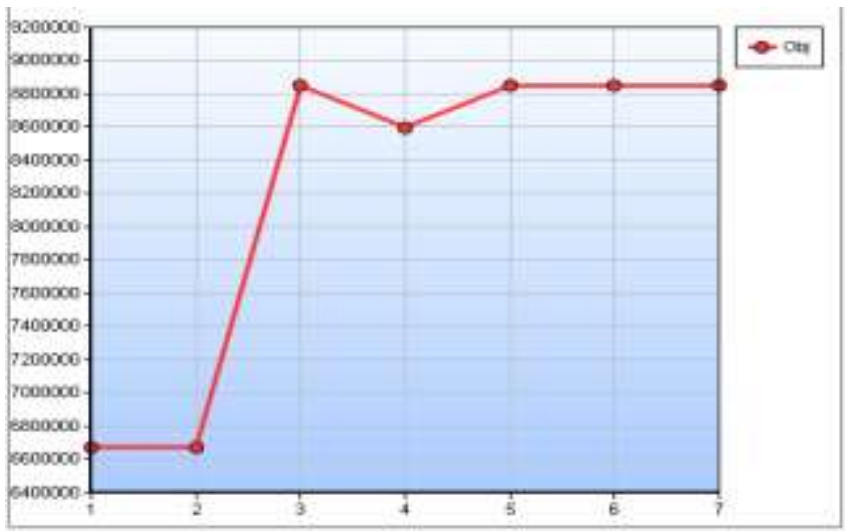

Figure 2. Iteration of the Solution

Source: Data Processed with LiPS program 
Based on the output of the program above, it is found that the maximum profit for the entire product is Rp. 18,850,000 with details is Rp. 12,250,000 crabs, Rp. 4,350,000 salt, Rp. 1,500,000 terasi and Rp. 750,000 empek-empek. Based on the output, it is also found that the profit will be maximized if it does not produce shredded fish and fish crackers. If you want to get the maximum profit, then the production level of crab must be done 10/3 times the normal amount, then salt is produced 2.5 times, empek-empek and shrimp paste are produced 2 times the usual amount.

If you still want to produce shredded fish, then to achieve maximum profit, the profit that should be generated in the production of shredded fish is Rp. 125,000, while for fish crackers it is Rp. 100,000

\section{CONCLUSION}

Optimization of processed fishery products in Teluk Santong Village by using linear programming produces a maximum profit of Rp. 18,850,000, - with details is Rp. 12,250,000 crabs, Rp. 4,350,000 salt, Rp. $1,500,000$ terasi and Rp. 750,000 empek-empek. To be able to get the maximum profit, the strategy that needs to be done is to increase the production of crab production by 10/3 times the normal amount, then salt is produced 2.5 times, empek-empek and shrimp paste are produced 2 times the usual production., and do not develop or produce shredded fish and fish crackers.

The model developed by the researcher does not involve a demand limit for each product due to the difficulty in describing the demand for products that are still in the micro category. For this reason, for the development of further research, it is necessary to take a portrait of the number of requests and other factors such as marketing, warehousing and human resources involved in the production of processed fishery products in Teluk Santong Village.

\section{REFFERENCE}

1. Alam, TB, Megasari, A., Amalia, SA, Maulani, G., Mahuda, I., Bangsa, UB, Programmin, L., \& Simpleks, M. (2021). Using Linear Programming Through Method. 1(2), 190-207.

2. Andarwulan, N., Kusnandar, F., \& Herawati, D. (2011). Food Analysis. PT. People's Diane. Jakarta.

3. Diedrich, A., Blythe, J., Petersen, E., Euriga, E., Fatchiya, A., Shimada, T., \& Jones, C. (2019). Socio-economic drivers of adoption of small-scale aquaculture in Indonesia. Sustainability (Switzerland), 11(6). https://doi.org/10.3390/su11061543

4. Directorate General of Strengthening the Competitiveness of Marine and Fishery Products. (2018). Business Potential and Investment Opportunities for Marine and Fisheries of West Nusa Tenggara Province. Marine and Fisheries Ministry.

5. Kakay, \& J, T. (2008). Linear Programming Methods and Problems. Andi Offset.

6. Karo, (Natalia). (2016). Analysis of Bulog Rice Distribution Optimization in West Java Province. MIX: Scientific Journal of Management, 6(1). https://doi.org/10.22441/jurnal_mix

7. Mahardana, Ambarwati, I., \& Ustriyana, I. (2015). Analysis of the added value of processed fish business (the case of the Dual Single Processing and Marketer Group in Banjar Penganggahan, Tengkudak Village, Penebel District, Tabanan Regency). E-Journal of Agribusiness and Agritourism (Journal of Agribusiness and Agritourism), 4(2).

8. Parnanto, NHR, \& Atmaka, W. (2010). Diversification and Characterization of the Taste of Mackerel Fish Meatballs (Scomberomus Commerson) With the Addition of Coconut Shell Liquid Smoke. Journal of Agricultural Products Technology, 3(1). https://doi.org/10.20961/jthp.v0i0.13612

9. Riniwati, H. et al. (2020). Marketing Distribution Optimization Model for Processed Catfish. ECSOFiM, 8(1), 6781. https://doi.org/10.21776/ub.ecsofim.2020.008.01.06

10. Widyaningsih, \& Martini. (2006). Instant Meatball Quality Improvement With Chitossan Procedure. Journal of Preservation, 9(4), 307-313.

11. Ziegel, ER, \& Winston, W. (1988). Operations Research: Applications and Algorithms. Technometrics, 30(3). https://doi.org/10.2307/1270107 